\title{
Numerical Simulation and Engineering Application of Coalbed Water Injection
}

\author{
Yijie Shi, ${ }^{1}$ Pengfei Wang $\mathbb{D}^{2,3}$ Ronghua Liu, ${ }^{1,3}$ Xuanhao Tan, ${ }^{1}$ and Wen Zhang ${ }^{1}$ \\ ${ }^{1}$ School of Resource, Environment \& Safety Engineering, Hunan University of Science \& Technology, Xiangtan, \\ Hunan 411201, China \\ ${ }^{2}$ Work Safety Key Lab on Prevention and Control of Gas and Roof Disasters for Southern Coal Mines, \\ Hunan University of Science \& Technology, Xiangtan, Hunan 411201, China \\ ${ }^{3}$ Hunan Provincial Key Laboratory of Safe Mining Techniques of Coal Mines, Hunan University of Science \& Technology, \\ Xiangtan 411201, China
}

Correspondence should be addressed to Pengfei Wang; pfwang@sina.cn

Received 8 October 2019; Accepted 26 November 2019; Published 17 December 2019

Academic Editor: Alessandro Mauro

Copyright ( 2019 Yijie Shi et al. This is an open access article distributed under the Creative Commons Attribution License, which permits unrestricted use, distribution, and reproduction in any medium, provided the original work is properly cited.

Coalbed water injection is the most basic and effective dust-proof technology in the coal mining face. To understand the influence of coalbed water injection process parameters and coalbed characteristic parameters on coal wetting radius, this paper uses Fluent computational fluid dynamics software to systematically study the seepage process of coalbed water injection under different process parameters and coalbed characteristic parameters, calculation results of which are applied to engineering practice. The results show that the numerical simulation can help to predict the wetness range of coalbed water injection, and the results can provide guidance for the onsite design of coalbed water injection process parameters. The effect of dust reduction applied to onsite coalbed water injection is significant, with the average dust reduction rates during coal cutting and support moving being $67.85 \%$ and $46.07 \%$, respectively, which effectively reduces the dust concentration on the working face and improves the working environment.

\section{Introduction}

Coal is the main energy source in China, accounting for about two-thirds of total primary energy consumption [1-5]. Plenty of environmental problems and natural disasters may occur during mining, i.e., roof fall, gas, fire, and dust pollution [6-9]. In recent years, with the rapid development of coal mining technology and the wide application of highpower mining machines, the amount of dust produced in coal mining places increased sharply and the working environment has deteriorated, which seriously threaten the safety of mine production and the health of workers [10-14]. According to the actual measurement, at present, when dust control measures are not taken in coal mining face, the dust concentration can reach $3000 \mathrm{mg} / \mathrm{m}^{3}$ [15-18]. Even if the measures are taken, the working environment of most mining faces still very bad and the dust concentration in the working place of mining drivers can reach $400-900 \mathrm{mg} / \mathrm{m}^{3}$ [19-22]. According to the Statistical Report on Occupational Diseases issued by the National Health and Health Commission of China, a total of 23,497 new cases of occupational diseases were reported in 2018, in which 19,468 cases were pneumoconiosis, accounting for $82.85 \%$ of the total number of reports. In terms of industry distribution, the newly added cases of pneumoconiosis were mainly distributed in coal mining and nonferrous metal mining industries, of which coal mining industry accounts for about $40 \%$ of the total number of pneumoconiosis reports [23-25].

At present, coalbed water injection, ventilation for dust control, dust control by using dust remover, dust-settling by spray, foam dedusting, and sealing dust isolation are mainly used in coal mining face at home and abroad [26-32]. It is widely believed in all coal-producing countries at home and abroad that coalbed water injection is the most basic and 
effective dust-proof technology in the mining face. The basic dust-proof mechanism of coal seam water infusion is to infuse water into the coalbed advance before mining to increase the moisture content and wettability of the coal body and reduce the amount of dust produced by the mining machine. As early as the 1960s, the mine supervision bureaus of German coal-producing states all expressly stipulated that the coal body must be infused with water before mining in the coal mining face, and the coalbed water injection equipment included a pneumatic pump, constant flow control valve, hydraulic expansion sealing device, etc. The Institute of Mining Mechanics of the Ukrainian Academy of Sciences of the USSR has developed the YHP-type water infusion pump which can automatically adjust the water injection parameters according to the permeability characteristics of the coalbed. France Coal Center has developed flow controller and continuous water injection device, which make coalbed water injection automated [33].

China began to popularize the use of coalbed water injection dust-proof technology in the 1970s. Du from Chongqing Coal Science Research Institute analyzed the influence of the water injection system and pressurization way on the dust prevention effect of water injection in long drilled coalbed. Li et al. [34, 35] used the finite element numerical method to simulate the water injection process of thick coalbeds and qualitatively analyzed the dynamic relationship between process parameters such as water injection pressure, water injection time, borehole spacing, and wetness range. Zhao [36] and Cheng et al. [37, 38] proposed a variable-frequency pulsed water injection technology for low-permeability and high-hardness coalbeds which are difficult in water injection and achieved a satisfactory effect. Li et al. $[39,40]$ applied the MTS electrohydraulic servo rock test system to carry out a research on the permeability characteristics of deep coal and rock specimens under high pore water pressure. Based on a self-developed coalbed water injection experimental platform, Cheng et al. [41, 42] established a mathematical model of nonlinear seepage flow in the gassy coalbed water injection process and revealed water-injection dynamic characteristics of coalbeds. Xu et al. [43] applied COMSOL software to consider coal deformation parameters and obtain the law of coal stress and strain on the coalbed water injection effect. Qin et al. [44, 45] proposed an orthogonal design optimization method for water injection parameters of coalbed in accordance with the characteristics of dynamic changes in engineering geological factors of coalbed water injection. Yuan et al. [46, 47] established fisher discriminative model via fuzzy integral, which provided a scientific basis for the determination of the difficulty in coalbed water injection.

Based on the above research status, we can find that the great progress have been made in new technology for coalbed water injection, such as the variable-frequency pulsed water injection technology and the high-pressure water injection, and the relevant equipments were successfully developed. At the same time, the above research status shows that there are many qualitative researches on the relationship between coalbed water injection process parameters and wetting radius, with few corresponding quantitative studies. Moreover, the existing research on the impact of coalbed water injection parameters mainly focus on process parameters such as water injection time and water injection pressure, involving less coalbed characteristics and borehole diameters. Because of the above defects, onsite water injection parameter selection in engineering application often depends on empirical formulas or a large number of engineering tests, which leads to unsatisfied effect of coalbed water injection and dust reduction.

In view of the above disadvantages in coalbed water injection, in this paper, Fluent fluid mechanics calculation software is used to model the coalbed of 92103 working face in Chacheng Coal Mine of Xuzhou Coal Mining Group and simulate its seepage process of water injection. In addition, the influence of water injection process parameters such as water injection time, water injection pressure and borehole diameter, and coalbed characteristic parameters on wetting radius is explored, so as to provide a theoretical reference for the application of water injection and dust reduction engineering in coalbeds.

\section{Establishment of the Physical and Mathematical Models}

2.1. Physical Model. The geological data of 92103 working face in Chacheng Coal Mine of Xuzhou Coal Mining Group were collected and analyzed. On this basis, a three-dimensional seepage CFD model for porous media in waterinfused coalbeds was established. We select a rectangular parallelepiped of length $\times$ width $\times$ height $=12.5 \mathrm{~m} \times 10.0 \mathrm{~m} \times$ $1.2 \mathrm{~m}$ as the calculation area and one borehole with a length of $8.3 \mathrm{~m}$ and a diameter of $42-108 \mathrm{~mm}$, and the coalbed inclination is $0^{\circ}$. Tet/Hybrid mixed tetrahedrons are used to mesh where the internal scale is set to 0.2 , and the number of meshes is 1022477. The calculation model is shown in Figure 1.

\subsection{Control Equation}

2.2.1. Continuity Equation. During numerical calculation, the coal body is regarded as a porous medium region, and the water injection process of the coalbed is the fluid flow of water through the porous media, the continuity equation of which can be described as

$$
\frac{\partial \rho}{\partial t}+\nabla\left(\rho v_{i}\right)=0
$$

where $\rho$ is the density of water, $\mathrm{kg} / \mathrm{m}^{3} ; t$ is the time, $s ; v_{i}$ is the velocity component of $x, y$, and $z$ coordinate directions, $\mathrm{m} / \mathrm{s}$.

2.2.2. Momentum Equation of Porous Media. Momentum equations for porous media have additional momentum source terms that can be expressed as

$$
\frac{\partial}{\partial t}\left(\rho v_{i}\right)+\nabla\left(\rho v_{i} v_{i}\right)=-\nabla p+\nabla \tau_{i j}+\rho f_{i}-S_{i}
$$

where $p$ is the water pressure in the coal body, $\mathrm{Pa} ; f_{i}$ is the component of the fluid body force of a unit mass in direction 


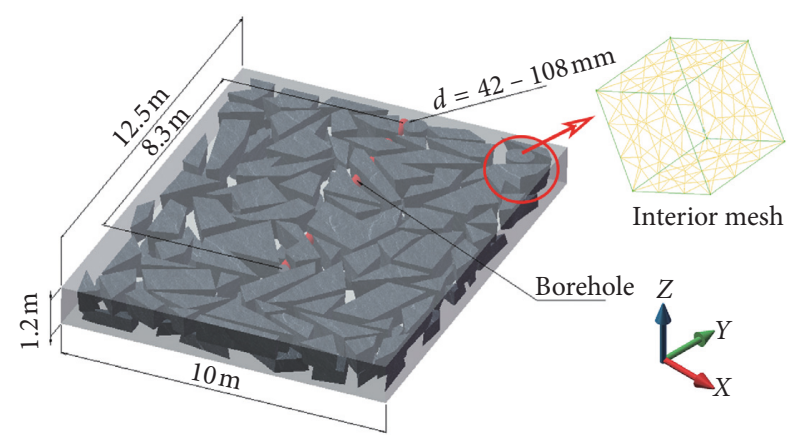

FIgURE 1: Calculation model of coalbed water injection.

$i, \mathrm{~m} \cdot \mathrm{s}^{-2} ; \tau_{i j}$ is the fluid internal viscous force, $\mathrm{kg} \cdot \mathrm{m} \cdot \mathrm{s}^{-2}$; and $S_{i}$ is an additional power source term in direction $i$ and consists of two parts, viscous loss and internal loss. For each isotropic porous medium, the additional momentum source term $S_{i}$ can be expressed as

$$
S_{i}=-\left(\frac{\mu}{\alpha} v_{i}+C \frac{1}{2} \rho|v| v_{i}\right)
$$

where $\mu$ is the viscous coefficient of the fluid, Pa.s; $\alpha$ is the permeability, $\mathrm{m}^{2}$; $C$ is the inertial resistance coefficient, $\mathrm{m}^{-1}$; $|v|$ is the speed, $\mathrm{m} / \mathrm{s}$. The permeability $\alpha$ and inertial resistance coefficient $C$ can be calculated according to the Blake-Kozeny equation [48-50]:

$$
\begin{gathered}
\alpha=\frac{D_{p}^{2}}{150} \frac{\varepsilon^{3}}{(1-\varepsilon)^{2}}, \\
C=\frac{3.5}{D_{p}} \frac{(1-\varepsilon)}{\varepsilon^{3}},
\end{gathered}
$$

where $D_{p}$ is the average particle diameter, usually taking the value $0.011 \mathrm{~m}$, and $\varepsilon$ is the porosity of the porous medium.

2.3. Boundary Conditions and Parameter Settings. The water injection borehole boundary is set as the pressure-inlet boundary, the inlet static pressure is $2-12 \mathrm{MPa}$, and the initial flow speed is $2.0 \mathrm{~m} / \mathrm{s}$; The boundaries around the coalbed are set as the pressure-outlet. The upper and lower boundaries of the coalbed are set as the wall. The interface between the borehole and the coalbed is set as the interior. The calculated coalbed body is set as porous media, and the porosity parameter of the coalbed is set as 0.04 to 0.12 according to calculation requirements. Viscosity resistance $1 / \alpha$ and inertial resistance $C$ can be calculated according to equations (4) and (5), respectively. The results are shown in Table 1.

\section{Numerical Simulation Results and Analysis}

3.1. Coalbed Water Injection Effect Index. The effect of coalbed water injection is generally evaluated by moisture increment of the coal which is related to parameters such as water injection time, water injection pressure, porosity of the coal, and diameter of the borehole. During water injection of the coalbed, the calculation formula of the coal body specific storage rate shown in the seepage process from unsaturated to saturated can be expressed as [35]

$$
S=\theta \rho g\left(\frac{\alpha_{p}}{\varepsilon}+\beta\right)+\frac{\partial \theta}{\partial p_{\mathrm{L}}},
$$

where $S$ is the coal body specific storage rate $\mathrm{Pa}^{-1} ; \theta$ is the volumetric water content; $\alpha_{p}$ is the compressibility coefficient of the porous medium skeleton, $\mathrm{MPa}^{-1} ; \mathrm{p}_{\mathrm{L}}$ is the water pressure in the coal body, $\mathrm{MPa}$; and $\beta$ is the elastic compressibility coefficient of water, $\mathrm{MPa}^{-1}$. The elastic compressibility coefficient of water $\beta$ can be calculated by the following formula:

$$
\beta=\beta_{\mathrm{w}}\left(p_{\mathrm{L}}-p_{0}\right)=4.5 \times 10^{-4}\left(p_{\mathrm{L}}-0.1\right),
$$

where $\beta_{\mathrm{w}}$ is the compressibility coefficient of water under standard atmospheric pressure, which is taken as $4.5 \times 10^{-4} \mathrm{MPa}^{-1}$ and $p_{0}$ is the standard atmospheric pressure, which is taken as $0.1 \mathrm{MPa}$.

If the moisture content and the pressure head change rate are chosen to be constants and the moisture content change caused by the natural seepage, i.e., water absorption and diffusion, is ignored, then the moisture increment in the coalbed under pressure $p$ will be

$$
f=\frac{S p_{\mathrm{L}}}{\rho_{\mathrm{c}}}
$$

The moisture increment can be approximated as

$$
f=\frac{\rho g \varepsilon\left(\alpha_{p}+\beta\right)}{\rho_{\mathrm{c}}} p_{\mathrm{L}},
$$

where $f$ is the moisture increment of the coalbed; $\rho_{\mathrm{c}}$ is the density of the coal body; and $\alpha_{p}$ is the compressibility coefficient of the pore skeleton of porous media coalbed, $\mathrm{MPa}^{-1}$. The value of $\alpha_{p}$ is related to the overburden pressure, and according to the buried depth of the applied working face $(900 \mathrm{~m})$ and the average temperature $\left(38^{\circ} \mathrm{C}\right)$, the skeleton compression coefficient $\alpha_{p}$ is taken as $0.063 \mathrm{MPa}^{-1}$. According to equations (7) and (9), water pressure of the coalbed corresponding to different moisture increments for various porosity coalbeds can be calculated, as shown in Table 2 .

Coalbed moisture increment of $1 \%$ is usually used as an indicator of the wetting radius. The Fluent simulation results are imported into Tecplot for postprocessing, and 7 levels of pressure isoline corresponding to moisture increment is set. When extracting the $3 \mathrm{rd}$ level and the moisture increment is $1 \%$, the maximum distance in the $x$-direction will be the current wetting radius.

3.2. Effect of Water Injection Time on Wetting Radius. The porosity and borehole diameter of the coalbed are set as $4 \%$ and $63 \mathrm{~mm}$, respectively. Fluent software is used to simulate the water injection conditions of coalbed under three kinds of water supply pressure $(2,4$, and $6 \mathrm{MPa})$, and the calculation continues for 40 hours to examine the influence of water injection time on the wetting radius and borehole water flow rate. The experimental results are shown in Table 3. 
TABLE 1: Coalbed seepage parameter setting.

\begin{tabular}{lcccc}
\hline No. & Porosity $n(\%)$ & Permeability $\alpha\left(\mathrm{m}^{2}\right)$ & Viscosity resistance $1 / \alpha\left(\mathrm{m}^{-2}\right)$ & ${\text { Inertial resistance } C\left(\mathrm{~m}^{-1}\right)}^{-1}$ \\
\hline 1 & 4 & $1.400 \times 10^{-9}$ & $7.140 \times 10^{8}$ & $4.773 \times 10^{6}$ \\
2 & 6 & $3.286 \times 10^{-9}$ & $3.043 \times 10^{8}$ & $1.385 \times 10^{6}$ \\
3 & 8 & $6.099 \times 10^{-9}$ & $1.639 \times 10^{8}$ & $5.717 \times 10^{5}$ \\
4 & 10 & $9.958 \times 10^{-9}$ & $1.004 \times 10^{8}$ & $2.864 \times 10^{5}$ \\
5 & 12 & $1.500 \times 10^{-8}$ & $6.667 \times 10^{7}$ & $1.620 \times 10^{5}$ \\
\hline
\end{tabular}

TABLE 2: Water pressure of the coalbed corresponding to different moisture increments $(\mathrm{MPa})$.

\begin{tabular}{lcccccccc}
\hline \multirow{2}{*}{ No. Porosity $\varepsilon(\%)$} & \multicolumn{8}{c}{ Moisture increment $f(\%)$} \\
& & 0.1 & 0.5 & 1.0 & 1.5 & 2.0 & 2.5 & 3.0 \\
\hline 1 & 4 & 0.054 & 0.27 & 0.53 & 0.80 & 1.06 & 1.33 & 1.59 \\
2 & 6 & 0.035 & 0.18 & 0.36 & 0.53 & 0.71 & 0.89 & 1.06 \\
3 & 8 & 0.026 & 0.13 & 0.27 & 0.40 & 0.53 & 0.67 & 0.80 \\
4 & 10 & 0.021 & 0.11 & 0.22 & 0.32 & 0.43 & 0.53 & 0.64 \\
5 & 12 & 0.018 & 0.089 & 0.18 & 0.27 & 0.36 & 0.45 & 0.53 \\
\hline
\end{tabular}

TABLE 3: Effect of injection time on wetting radius and borehole water flow rate.

\begin{tabular}{lcccccc}
\hline \multirow{2}{*}{ Injection time/h } & \multicolumn{3}{c}{ Wetting radius $(\mathrm{m})$} & \multicolumn{3}{c}{$\begin{array}{c}\text { Borehole water flow } \\
\text { rate }\left(\mathrm{L} \cdot \mathrm{min}^{-1}\right)\end{array}$} \\
& $2 \mathrm{MPa}$ & $4 \mathrm{MPa}$ & $6 \mathrm{MPa}$ & $2 \mathrm{MPa}$ & $4 \mathrm{MPa}$ & $6 \mathrm{MPa}$ \\
\hline 1 & 0.05 & 0.13 & 0.49 & 8.2 & 11.6 & 14.3 \\
5 & 0.58 & 1.55 & 2.35 & 4.0 & 5.6 & 7.2 \\
10 & 0.76 & 1.95 & 2.78 & 2.2 & 3.1 & 3.9 \\
20 & 0.80 & 2.02 & 2.84 & 1.7 & 2.4 & 3.2 \\
30 & 0.81 & 2.03 & 2.85 & 1.6 & 2.3 & 3.1 \\
40 & 0.82 & 2.04 & 2.85 & 1.6 & 2.2 & 2.9 \\
\hline
\end{tabular}

As illustrated from Table 3, the wetting radius of the coalbed increases with time under the three water injection pressures, but the expansion of the wetting radius decreases rapidly after the water injection time reaches $10 \mathrm{~h}$. It can also be seen from Table 1 that the wetting radius of the coalbed has not changed significantly at water injection time of $20 \mathrm{~h}$ and $40 \mathrm{~h}$, which proves that the range of coalbed water injection will reach the limit after a certain time. As demonstrated in Table 3, the borehole water flow rate continuously declines with the rise of water injection time. In the early stage of water injection, the original coalbed is with low moisture content and it is far from saturation with strong water absorption capability and high borehole water flow rate. The wetness range rapidly boosts with the increased duration of water injection. However, after the water injection time reaches $10 \mathrm{~h}$, the coal specific storage tends to be saturated, the borehole water flow decreases significantly, and the increase of the wetting radius drops. As the water injection time continues to rise, the water in pores and fractures of the coalbed is basically saturated and the wetting radius does not augment significantly.

Figure 2 shows the distribution of water pressure in the coalbed under different water injection time when the water supply pressure is $4.0 \mathrm{MPa}$. The water pressure distribution in Figure 2 can also reflect the same trend described above, i.e., the wetting radius increases with time, but the wetness range reaches its limit after a certain time. Considering that the longer the injection time is, the higher the energy consumption is, and that the improvement of the wetting effect of long-term continuous water injection is not obvious, it is suggested that the water injection time should be reasonably controlled in the actual water injection process based on the permeability of the coalbed, the diameter of the borehole, and the water injection pressure.

\subsection{Effect of Water Supply Pressure on Wetting Radius.} While keeping the coal porosity (4\%) and borehole diameter $(63 \mathrm{~mm})$ constant, the interaction between water injection pressure and wetting radius is investigated by changing the water injection pressure with water injection time of $10 \mathrm{~h}$. The result is shown in Figure 3.

It is illustrated from Figure 3(a) that the wetting radius of water injection in coalbed augments with the increase of water injection pressure, but the augmentation in wetting radius tends to decrease, and the wetting radius of $10 \mathrm{MPa}$ is similar to that of $12 \mathrm{MPa}$. When the internal resistance of the coal body is constant, the borehole water flow will increase with the injection pressure, as shown in Figure 3(b). Meanwhile, under the effect of high-pressure water flow, the internal cracks of the coal body expand and the coal specific storage increases, making the wetness range rise with the water injection pressure. In the field application of coal water injection, if the water injection pressure is too high, the fracture structure of the coal itself will be destroyed, which will affect the seepage and migration of the water flow of the coal, resulting in poor water injection effect. Considering that the higher the injection pressure, the higher the water injection equipment requirements and energy consumption, the injection pressure is generally reasonable at $8 \mathrm{MPa}$. According to the principle of seepage, capillary action, and diffusion movement of water in the coal body, it is suggested that, in the actual water injection process, high-pressure water injection $(8 \mathrm{MPa})$ lower than the overburden pressure of the coalbed is used in the early stage to expand and communicate with the seepage channels of the coal pore fractures. In the later stage of coalbed water injection, if conditions permit, it is recommended to adopt low-flow and long-term low-pressure water injection $(2 \mathrm{MPa})$ to enable capillary and diffusion movements of water in the coal body in order to achieve the optimum wetting effect.

3.4. Effect of Coalbed Porosity on Wetting Radius. While keeping the borehole diameter $(63 \mathrm{~mm})$ unchanged and setting the water injection pressure as $8 \mathrm{MPa}$, five kinds of coalbed with different porosity $(4 \%, 6 \%, 8 \%, 10 \%$, and $12 \%)$ 


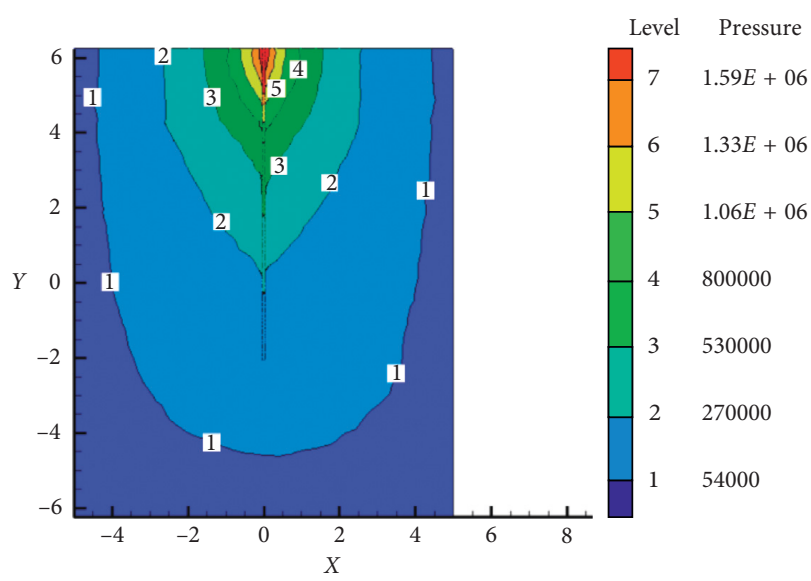

(a)

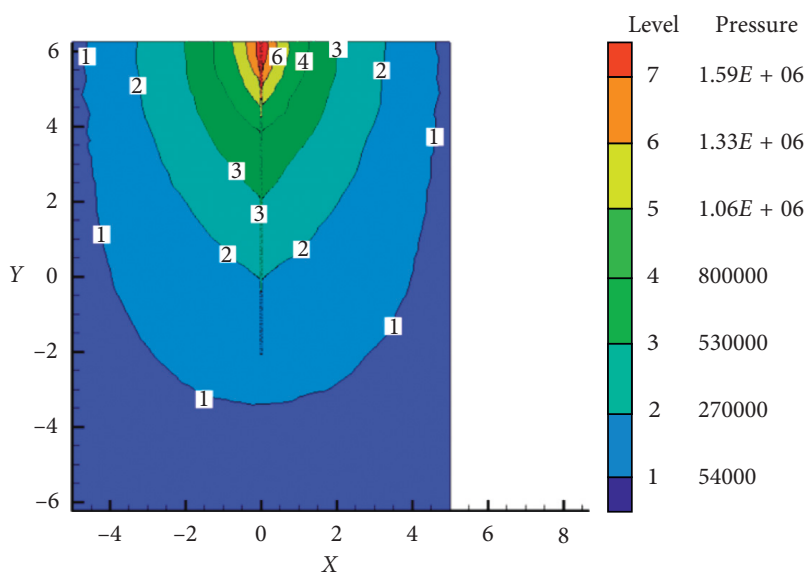

(c)

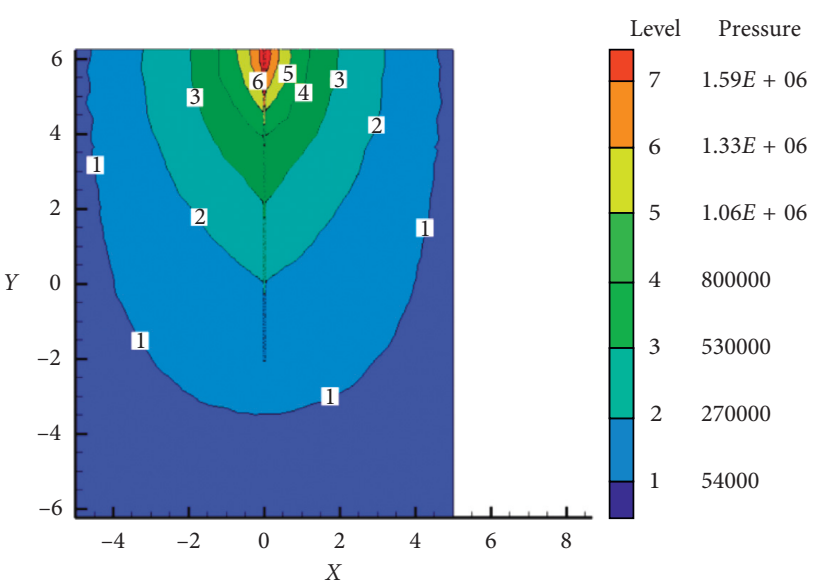

(b)

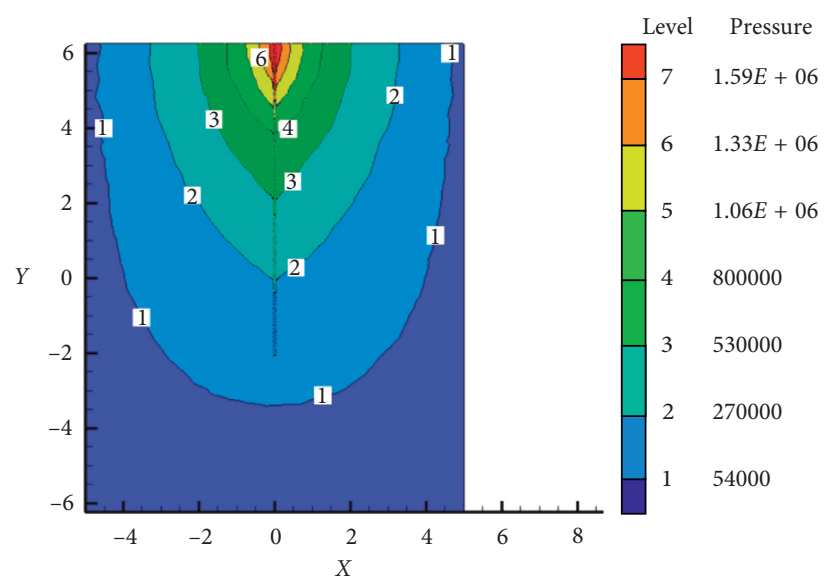

(d)

FIGURE 2: Water pressure distribution of coalbed changes with water injection time under water injection pressure of $4 \mathrm{MPa}$ : water injection for (a) $5 \mathrm{~h}$; (b) $10 \mathrm{~h}$; (c) $20 \mathrm{~h}$; and (d) $40 \mathrm{~h}$.

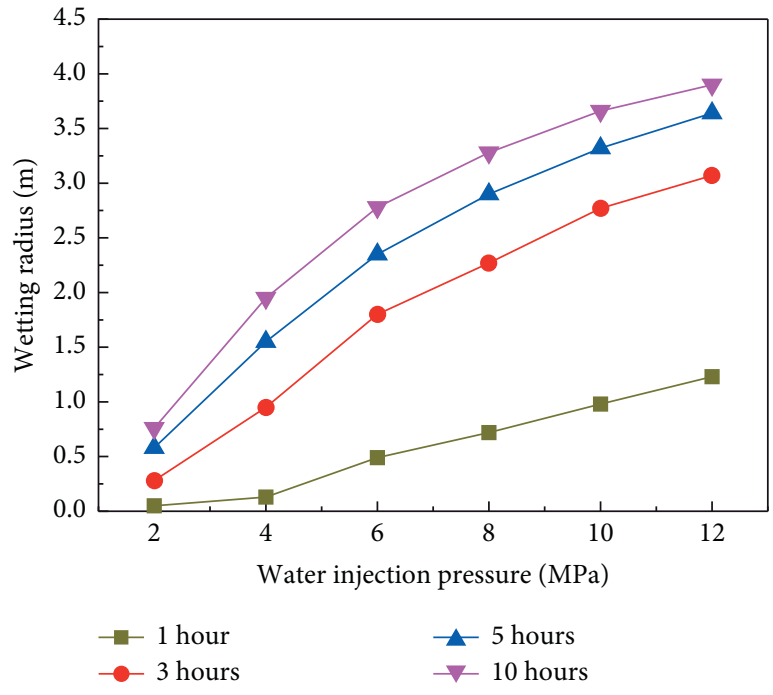

(a)

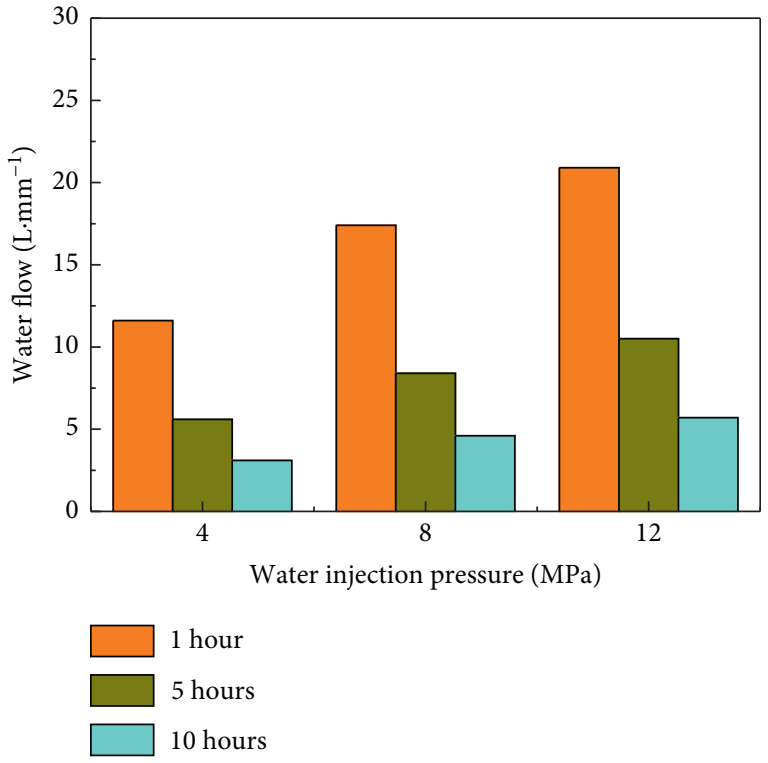

(b)

FIGURE 3: Effect of water injection pressure on wetting radius and borehole water flow: (a) wetting radius; (b) borehole water flow. 
are selected to simulate water injection for 10 hours to determine the relationship between porosity and wetting radius of the coalbed. The result of the calculation is shown in Figure 4.

As seen from Figure 4(a), when the water injection time is the same, the larger the porosity is, the smaller the wetting radius of the coalbed is. It is mainly because the greater the porosity of the coalbed, the larger the space occupied by its internal pore fractures and the greater the amount of water that a unit volume of coal can hold, resulting in a decrease in the wetting range at the same water injection time and injection pressure. Figure 4(b) shows the relationship between the borehole flow rate and the porosity of the coalbed, which demonstrates that the borehole flow rises with the porosity. According to the seepage theory of porous media, with the increase of porosity of the coalbed, the internal flow resistance of the coal body decreases and the borehole water flow rate boosts under the same water injection pressure. At the same water injection time, the larger the porosity is, the smaller the wetting radius of the coalbed is, but the larger the porosity is, the greater the total water injection and moisture content in the coalbed are and the moister the coal in the wet range is.

3.5. Effect of Bore Diameter on Wetting Radius. The porosity and injection pressure of the coalbed are set as $4 \%$ and $8 \mathrm{MPa}$, respectively, and four commonly used borehole diameters $(42 \mathrm{~mm}, 63 \mathrm{~mm}, 80 \mathrm{~mm}$, and $108 \mathrm{~mm})$ of the coalbed water injection are selected with 10 hours of water injection to investigate the influence of the borehole diameter on the wetting radius. The result of the calculation is shown in Figure 5.

As described from Figure 5, at the same water injection time, the larger the borehole diameter, the greater the wetness range of the coalbed. It is because when the pressure is the same, the larger the borehole diameter, the higher the borehole flow rate, the faster the moisture content of the coal body, and the greater the corresponding wetness range. It can also be seen from Figure 5 that, as the diameter of the borehole increases, the growth rate of the wetting radius becomes slower and the corresponding wetting radiuses for borehole diameters of $80 \mathrm{~mm}$ and $108 \mathrm{~mm}$ are very close, which demonstrates that after the borehole diameter reaches $80 \mathrm{~mm}$, the diameter of the coalbed will not change significantly with the further increase in the diameter of the borehole.

Figure 6 shows the water pressure distribution of the 4 types of borehole coalbed after water injection for 10 hours, which presents that, as the diameter of the borehole rises, the wetness range of the coalbed augments as well. By comparing Figures 6(c) and 6(d), it can be found that the range corresponding to the 3rd-level water pressure isoline (moisture increment of $1 \%$ ) is equivalent, i.e., there is no significant difference in the wetting radius between the two. However, the range covered by the 7 th-level pressure isoline (moisture increment of 3\%) corresponding to the diameter of the large borehole is significantly greater than the diameter of the small borehole, which proves that the large- diameter borehole makes the wetting more adequate. Regarding the field construction of water injection boreholes in the coalbed, the larger the borehole diameter, the larger the construction quantities, and the greater the borehole maintenance intensity. Considering that no obvious increase in the wetting radius of the coalbed after the diameter of the borehole increases to a certain extent is observed, boreholes with a diameter of $80 \mathrm{~mm}$ are recommended on the site of coal mines.

\section{Field Application of Coalbed Water Injection}

4.1. Technology and Equipment of Coalbed Water Injection. Chacheng Coal Mine is located in the east of Xuzhou Mining Area in Jiangsu Province and is a subordinate mine of Xuzhou Mining Group Co., Ltd. The designed production capacity of the mine is 600,000 tons per year. 92103 working face has an average coal thickness of $1.2 \mathrm{~m}$, a strike length of $560 \mathrm{~m}$, and an inclination of $125 \mathrm{~m}$. It adopts an inclined long-wall mining method for ascending mining. The primary moisture of the working face coal body is $2.78 \%$, the porosity is $4 \%$, the water absorption rate is $1.8 \%$, and the solidity coefficient is 5.8 , which meets the standard for water-injectable coalbeds.

The coalbed water injection this time adopts a long borehole water injection method. According to the coal thickness, the length of inclination, and the inclination of the coalbed, the borehole depth is designed to be $83 \mathrm{~m}$. According to the mining speed of the working face, the crossover distance of coalbed water injection is designed to be $40 \mathrm{~m}$. Moreover, based on the numerical simulation results and the actual conditions at the project site, a borehole with a diameter of $75 \mathrm{~mm}$ is selected. Numerical calculations show that the wetting radius of the coalbed is approximately $4.5 \mathrm{~m}$ when the borehole diameter is $80 \mathrm{~mm}$ and the borehole spacing is designed to be $8 \mathrm{~m}$. The water injection method for boreholes adopts the dynamic pressure water injection method, and the water injection pressure is selected as $8 \mathrm{MPa}$. Figure 7 is a schematic diagram of coalbed water injection layout on the working face.

The ZDY-1250 hydraulic tunnel drilling machine is used for water injection in the coalbed, and the borehole diameter is $75 \mathrm{~mm}$. The $5 \mathrm{BZ}-33 / 15$ pulsed coalbed water injection pump is selected, and the water injection time is $120 \mathrm{~h}$. An FKSS-63/4 type of hydraulic expansion sealer is used for sealing, and the sealing length is $1.5 \mathrm{~m}$. In order to ensure the balanced flow of porous injection water, a ZF-III equivalent shunt valve is used and the error is $\leq 5 \%$. The equipment used at the coalbed water injection site is shown in Figure 8.

4.2. Moist Effect of Coalbed Water Injection. The moisture increment before and after water injection in the coalbed, that is, the degree of wetness of the coal body, is the main index that determines the effect of water injection and dust reduction in the coalbed. It is generally believed that a positive dust-reducing effect can be obtained when the moisture content of the coal body increases by $1 \%$. After water injection in the coalbed of 92103 working face, 


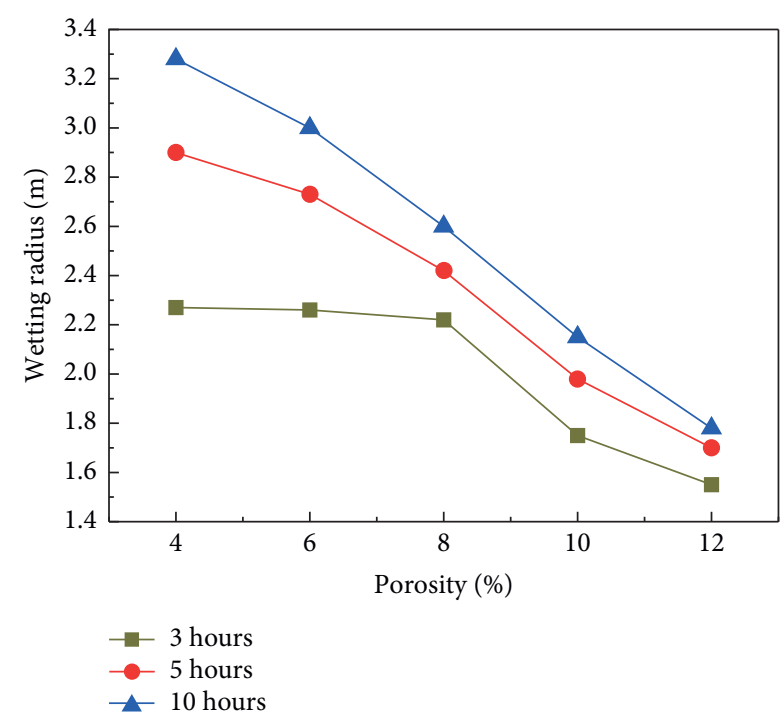

(a)

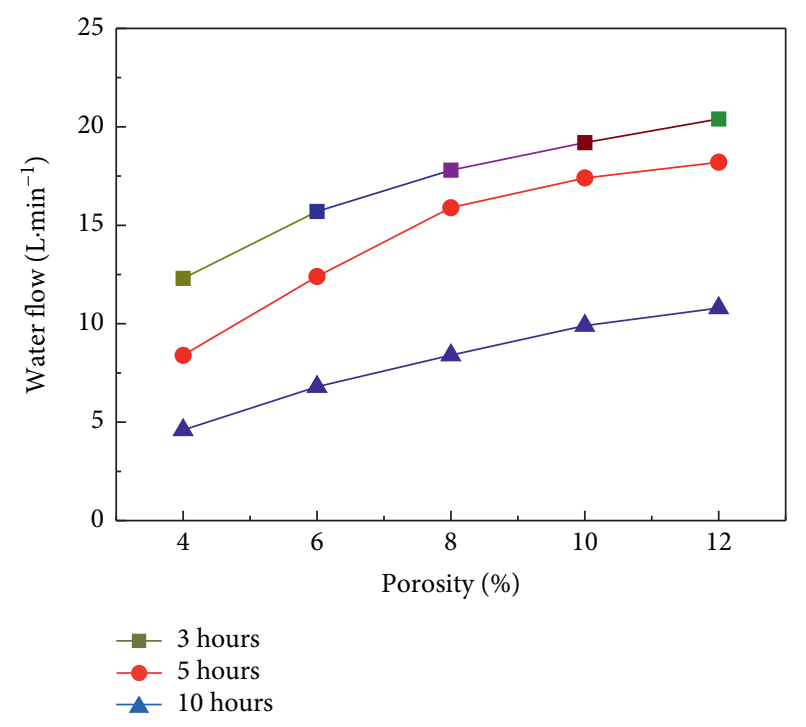

(b)

FIgURE 4: Influence of coal porosity on wetting radius and borehole water flow: (a) wetting radius; (b) borehole water flow.

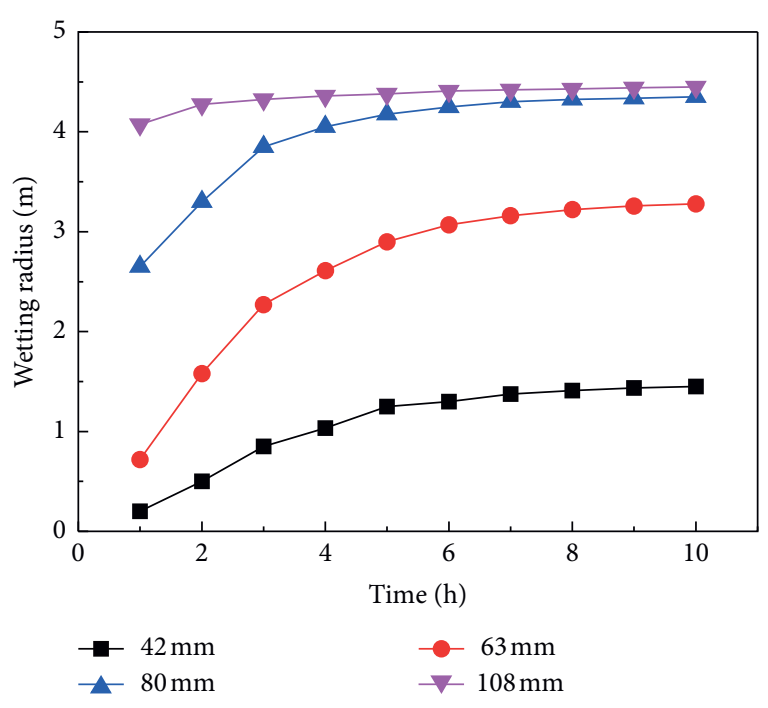

FIGURE 5: Relationship between wetting radius and borehole diameter.

borehole sampling will be used to test the total moisture in the coalbed. A hole is bored at 34, 35, 36, and $37 \mathrm{~m}$ away from the coal wall of the working face, respectively, with the borehole depth of $20 \mathrm{~m}$ and coal sampling every 5 meters of the drilling depth to measure the total moisture of the samples. The results are shown in Table 4.

From Table 4, it can be found that the moisture of the 4 coal samples corresponding to $1^{\#}$ borehole does not change significantly with respect to the original moisture of the coal, demonstrating that the coal within this range has not been substantially wetted, i.e., the samples are not within the wetting radius. The moisture contents of coal samples corresponding to boreholes \#2, \#3, and \#4 are higher than $3.78 \%$, and the increment of moisture after water injection is $1 \%$, which proves that the coal bodies near the boreholes are within the wetness range. In addition, the increase in the moisture content of the $2^{\#}$ borehole coal sample is exactly $1 \%$, indicating that the boundary of the wetness range is located near the $2^{\#}$ hole, i.e., the wetting radius is about $5 \mathrm{~m}$, which is basically the same as the result deduced by numerical simulation. From the above analysis, it is found that numerical simulation can be used to predict the wetness range of coalbed water infusion. The obtained results can provide guidance for the design of parameters such as borehole diameter, borehole spacing, and water injection pressure of coalbeds.

4.3. Dust Reduction Effect of Coalbed Eater Injection. In order to test the effect of water injection and dust reduction in coalbeds, four dust measurement points were selected before and after water injection on the 92103 working face to determine the dust mass concentration. Each dust measurement point is measured three times for average. The four dust measuring points include the position of the coal cutter driver, the downwind position $20 \mathrm{~m}$ away from the coal cutter driver, the position of the support move worker, and the downwind position $20 \mathrm{~m}$ away from the support move worker. The CCF-7000 direct-reading dust concentration analyzer is used at the measuring points to measure the dust concentration before and after water injection in the coalbed. The sampling time is set as $2 \mathrm{~min}$, and the sampling flow rate is $15 \mathrm{~L} / \mathrm{min}$ [51-54]. The measured dust concentration at each measurement point before and after water injection is shown in Figure 9.

From the measured data in Figure 9, it can be seen that the coal body is effectively moistened due to water injection in the coalbed, which greatly reduces dust production during the coal mining process. Measured dust concentration of the coal cutter driver and the downwind side of the coal cutter are significantly improved compared to measurement before water injection, and the average dust reduction rate reaches 


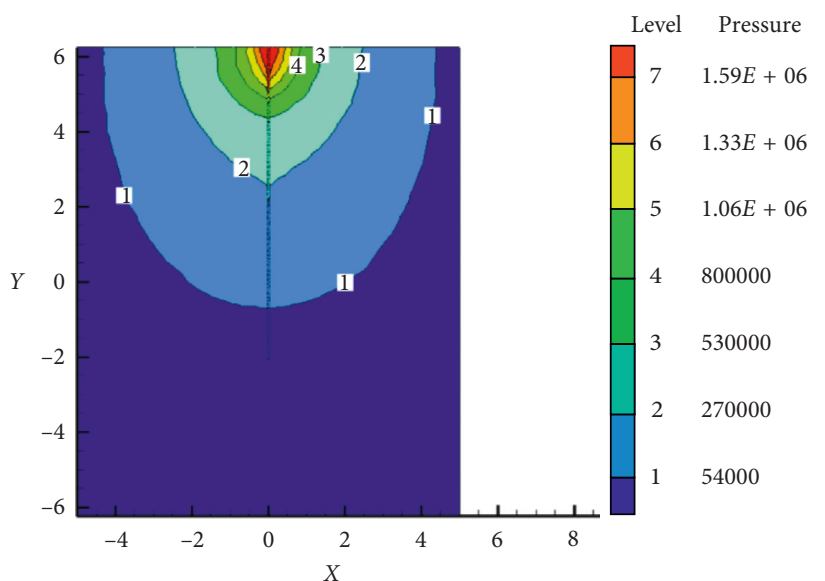

(a)

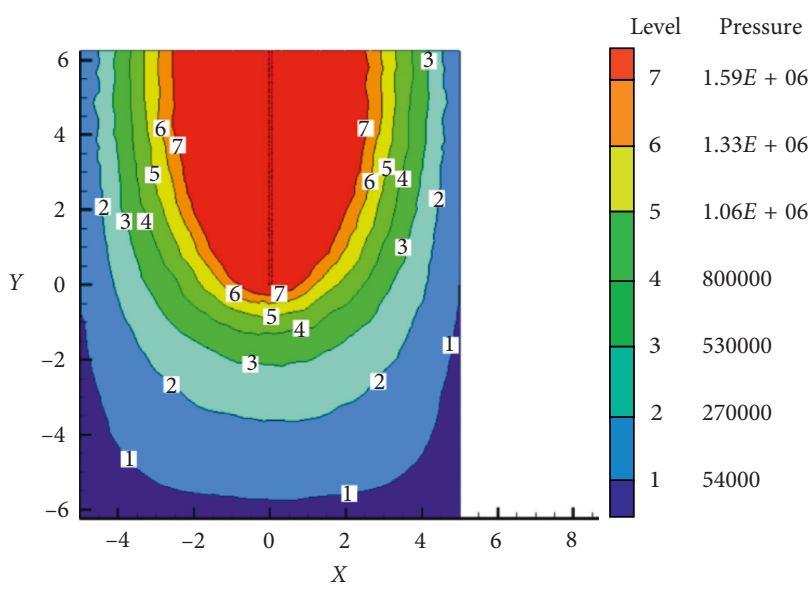

(c)

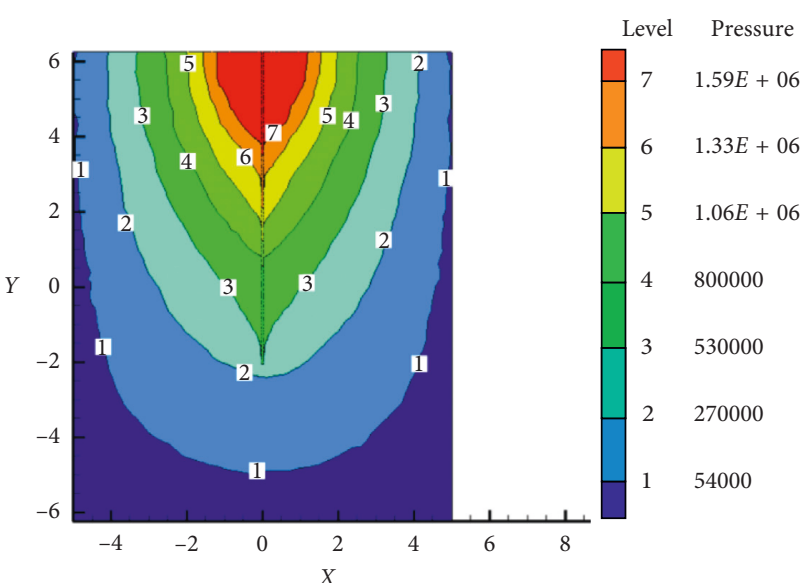

(b)

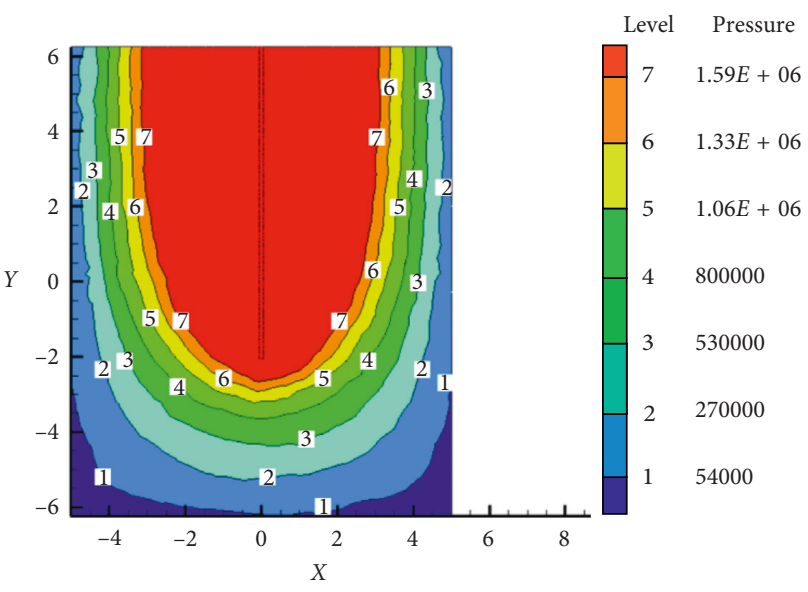

(d)

Figure 6: Coalbed water pressure distribution under different boreholes with $10 \mathrm{~h}$ water injection: borehole diameter of (a) $42 \mathrm{~mm}$; (b) $63 \mathrm{~mm}$; (c) $80 \mathrm{~mm}$; and (d) $108 \mathrm{~mm}$.

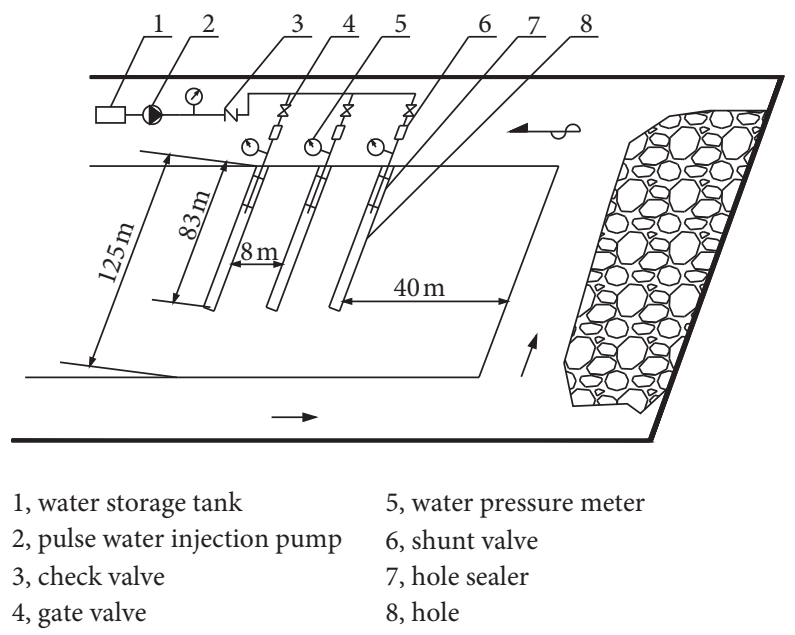

Figure 7: Long hole water injection layout of the coal mining face.

$67.58 \%$. In addition, part of the water in the water injection process penetrates into the permeable fracture of the coalbed, which results in a reduction in the amount of dust generated in the support move process, where the average dust reduction rate reaches $46.07 \%$. After the coalbed water injection on the fully mechanized coal mining face, the effect 


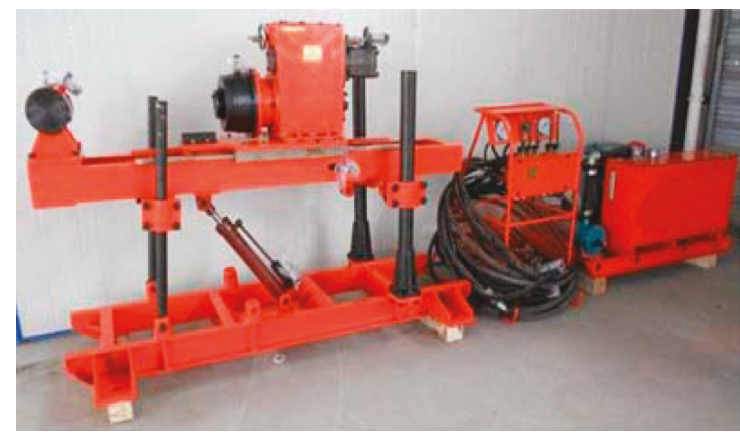

(a)

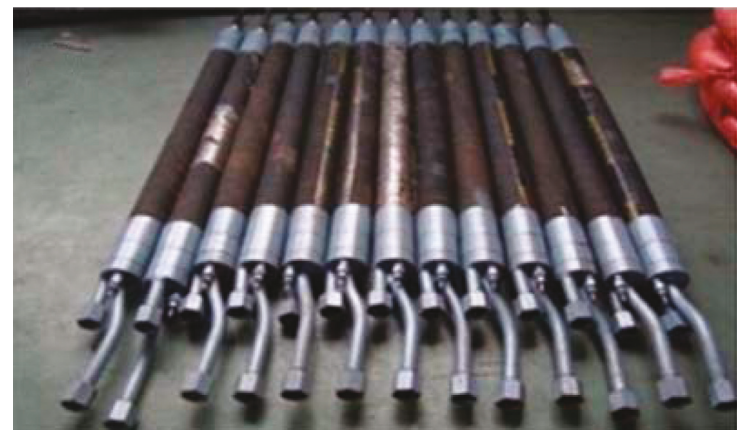

(c)

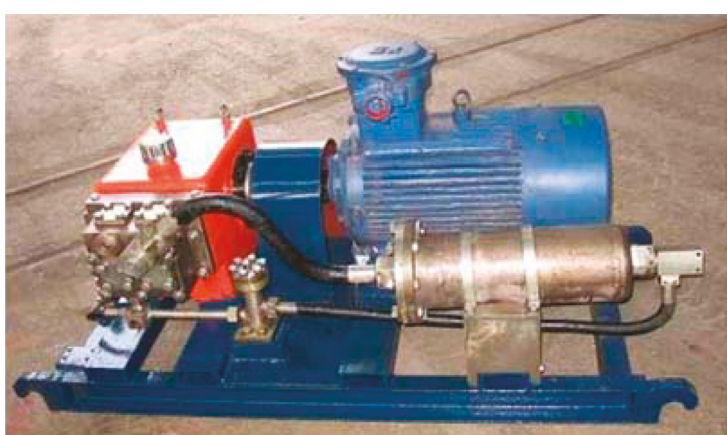

(b)

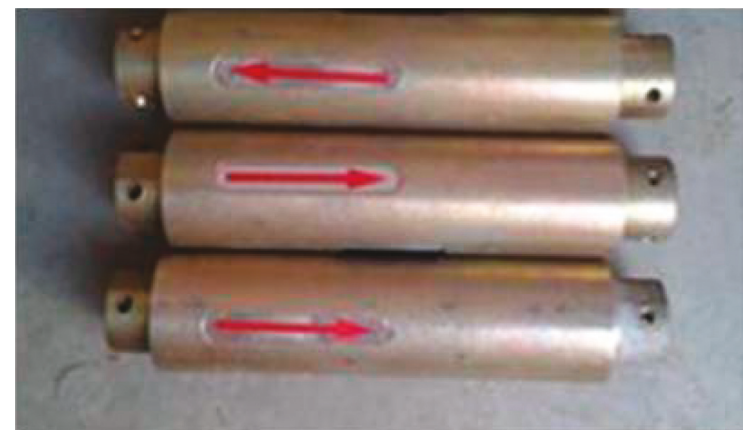

(d)

Figure 8: Equipment used at the coal injection site: (a) ZDY-1250 hydraulic tunnel drilling machine; (b) 5BZ-33/15 pulsed coalbed water injection pump; (c) FKSS-63/4 hydraulic expansion sealer; (d) ZF-III equivalent shunt valve.

TABLE 4: Total moisture of 92103 face after coalbed water injection.

\begin{tabular}{|c|c|c|c|c|c|c|}
\hline \multirow[b]{2}{*}{$\begin{array}{l}\text { Borehole } \\
\text { no. }\end{array}$} & \multirow[b]{2}{*}{$\begin{array}{l}\text { Distance from coal wall } \\
\qquad(\mathrm{m})\end{array}$} & \multicolumn{4}{|c|}{ Moisture after injection (\%) } & \multirow[b]{2}{*}{$\begin{array}{c}\text { Original moisture } \\
(\%)\end{array}$} \\
\hline & & $\begin{array}{l}\text { Borehole depth of } \\
5 \mathrm{~m}\end{array}$ & $\begin{array}{l}\text { Borehole depth of } \\
10 \mathrm{~m}\end{array}$ & $\begin{array}{l}\text { Borehole depth of } \\
15 \mathrm{~m}\end{array}$ & $\begin{array}{l}\text { Borehole depth of } \\
20 \mathrm{~m}\end{array}$ & \\
\hline $1^{\#}$ & 34 & 2.76 & 2.68 & 3.04 & 2.70 & \multirow{4}{*}{2.78} \\
\hline $2^{\#}$ & 35 & 3.78 & 3.82 & 3.89 & 3.93 & \\
\hline $3^{\#}$ & 36 & 3.86 & 3.96 & 4.00 & 4.21 & \\
\hline $4^{\#}$ & 37 & 3.88 & 4.01 & 4.13 & 4.45 & \\
\hline
\end{tabular}

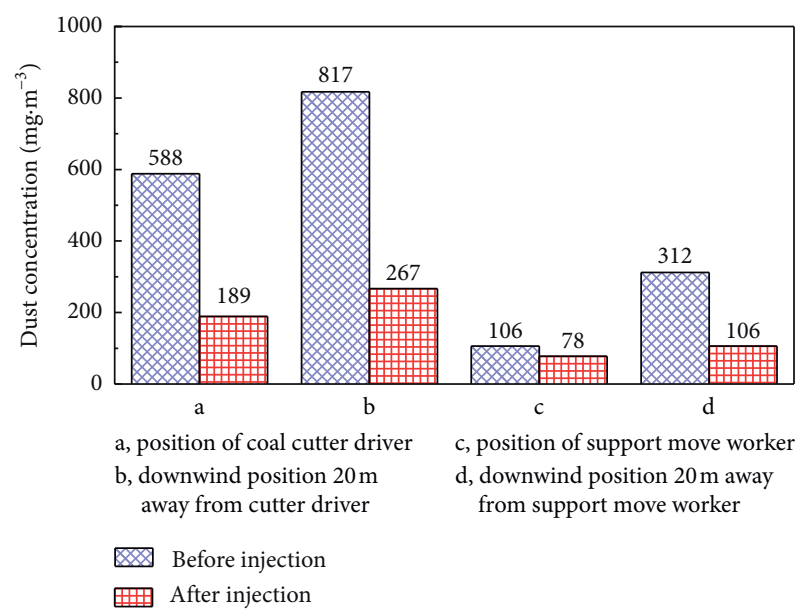

Figure 9: Contrast of dust concentration before and after water injection. of dust reduction is significant, which helps to effectively reduce the dust concentration in the working face and improve the working environment.

\section{Conclusions}

In this study, the physical model and the mathematical model of coalbed water infection are established. On this basis, the effects of water injection time, injection pressure, borehole diameters, and coalbed porosity on wetting radius are investigated by Fluent computational fluid dynamics software. The field application of coalbed water injection further proves that the numerical simulation can predict the wetting radius more accurately. By analyzing the results of numerical simulation and engineering application, the main conclusion can be drawn as follows:

(1) With the increase of water injection time, the wetting radius expands continuously, but the rising rate 
decreases continuously, and no obvious change is observed after the wet radius reaches a certain extent.

(2) The borehole water flow increases with the water injection pressure. In the same water injection time, the greater the water injection pressure is, the greater the range of coal wetness is.

(3) The greater the porosity of the coalbed, the greater the space occupied by the internal pore fissure channels, the greater the amount of water that a unit volume of coal can hold, and the smaller the wetting range at the same water injection time and water injection pressure; the same water injection time, the greater the porosity of the coalbed, the greater the total water injection and the moisture increment in the coalbed, and the moister the coal body in the wet range.

(4) When the injection pressure and water injection time are the same, the borehole water flow will increase with the borehole diameter and the wetness range of the coal body will increase as well. After the borehole diameter increases to a certain extent, no obvious increase in the wetting radius of the coalbed is shown. It is recommended that boreholes with a diameter of $80 \mathrm{~mm}$ be used on the coal mining site.

(5) Numerical simulation can be used to predict the water injection range of coalbeds, and the results can provide guidance for onsite design of parameters such as the borehole diameter, borehole spacing and water injection pressure of coalbeds. The effect of water injection and dust reduction in the coalbed is significant. The average dust reduction efficiencies during coal cutting and support moving is $67.58 \%$ and $46.07 \%$, respectively, thus effectively reducing the dust concentration at the working face and improving the working environment.

\section{Data Availability}

The data used to support the findings of this study are included within the article.

\section{Conflicts of Interest}

The authors declare that they have no conflicts of interest.

\section{Acknowledgments}

The authors gratefully acknowledge the financial support provided by the National Natural Science Foundation of China (No. 51574123) and the Scientific Research Project of Hunan Province Office of Education (No. 18A185).

\section{References}

[1] P. Cai, W. Nie, D. Chen, S. Yang, and Z. Liu, "Effect of air flowrate on pollutant dispersion pattern of coal dust particles at fully mechanized mining face based on numerical simulation," Fuel, vol. 239, pp. 623-635, 2019.
[2] Z. Liu, W. Nie, H. Peng, S. Yang, D. Chen, and Q. Liu, "The effects of the spraying pressure and nozzle orifice diameter on the atomizing rules and dust suppression performances of an external spraying system in a fully-mechanized excavation face," Powder Technology, vol. 350, pp. 62-80, 2019.

[3] G. Wang, X. J. Qin, J. N. Shen, Z. Y. Zhang, D. Y. Han, and C. H. Jiang, "Quantitative analysis of microscopic structure and gas seepage characteristics of low-rank coal based on CT three-dimensional reconstruction of CT images and fractal theory," Fuel, vol. 256, Article ID 115900, 2019.

[4] P. Wang, X. Tan, L. Zhang, Y. Li, and R. Liu, "Influence of particle diameter on the wettability of coal dust and the dust suppression efficiency via spraying," Process Safety and Environmental Protection, vol. 132, pp. 189-199, 2019.

[5] Z. Xiu, W. Nie, D. Chen et al., "Numerical simulation study on the coupling mechanism of composite-source airflow-dust field in a fully mechanized caving face," Powder Technology, vol. 356, pp. 443-457, 2019.

[6] M. Tao, Z. Li, W. Cao, X. Li, and C. Wu, "Stress redistribution of dynamic loading incident with arbitrary waveform through a circular cavity," International Journal for Numerical and Analytical Methods in Geomechanics, vol. 43, no. 6, pp. 1279-1299, 2019.

[7] W. D. Zhou, H. T. Wang, D. M. Wang, K. Zhang, Y. H. Du, and H. S. Yang, "The effect of geometries and cutting parameters of conical pick on the characteristics of dust generation: experimental investigation and theoretical exploration," Fuel Processing Technology, vol. 198, Article ID 106243, in Press.

[8] P. Wang, C. Tian, R. Liu, and J. Wang, "Mathematical model for multivariate nonlinear prediction of SMD of X-type swirl pressure nozzles," Process Safety and Environmental Protection, vol. 125, pp. 228-237, 2019.

[9] M. Wu, X. Hu, Q. Zhang, D. Xue, and Y. Zhao, "Growth environment optimization for inducing bacterial mineralization and its application in concrete healing," Construction and Building Materials, vol. 209, pp. 631-643, 2019.

[10] P. Chang, G. Xu, F. Zhou, B. Mullins, S. Abishek, and D. Chalmers, "Minimizing DPM pollution in an underground mine by optimizing auxiliary ventilation systems using CFD," Tunnelling and Underground Space Technology, vol. 87, pp. 112-121, 2019.

[11] J. Wang, G. Zhou, X. Wei, and S. Wang, "Experimental characterization of multi-nozzle atomization interference for dust reduction between hydraulic supports at a fully mechanized coal mining face," Environmental Science and Pollution Research, vol. 26, no. 10, pp. 10023-10036, 2019.

[12] Q. Liu, W. Nie, Y. Hua, H. Peng, C. Liu, and C. Wei, "Research on tunnel ventilation systems: dust diffusion and pollution behaviour by air curtains based on CFD technology and field measurement," Building and Environment, vol. 147, pp. 444-460, 2019.

[13] J. C. Kumia, A. P. Sasmito, and A. S. Mujumdar, "Dust dispersion and management in underground mining faces," International Journal of Mining Science and Technology, vol. 24, no. 1, pp. 39-44, 2014.

[14] W. Zhou, W. Nie, C. Liu et al., "Modelling of ventilation and dust control effects during tunnel construction," International Journal of Mechanical Sciences, vol. 160, pp. 358-371, 2019.

[15] D. Chen, W. Nie, P. Cai, and Z. Liu, "The diffusion of dust in a fully-mechanized mining face with a mining height of $7 \mathrm{~m}$ and the application of wet dust-collecting nets," Journal of Cleaner Production, vol. 205, pp. 463-476, 2018. 
[16] P. Wang, Y. Li, R. Liu, and Y. Shi, "Effects of forced-to-exhaust ratio of air volume on dust control of wall-attached swirling ventilation for mechanized excavation face," Tunnelling and Underground Space Technology, vol. 90, pp. 194-207, 2019.

[17] G. Xu, P. Chang, B. Mullins, F. Zhou, and S. Hu, "Numerical study of diesel particulate matter distribution in an underground mine isolated zone," Powder Technology, vol. 339, pp. 947-957, 2018.

[18] S. Yang, W. Nie, S. Lv et al., "Effects of spraying pressure and installation angle of nozzles on atomization characteristics of external spraying system at a fully-mechanized mining face," Powder Technology, vol. 343, pp. 754-764, 2019.

[19] H. Wang, X. Wei, Y. Du, and D. Wang, "Experimental investigation on the dilatational interfacial rheology of dustsuppressing foam and its effect on foam performance," Process Safety and Environmental Protection, vol. 123, pp. 351-357, 2019.

[20] Y. Ma, G. Zhou, J. Ding, S. Li, and G. Wang, "Preparation and characterization of an agglomeration-cementing agent for dust suppression in open pit coal mining," Cellulose, vol. 25, no. 7, pp. 4011-4029, 2018.

[21] P. Wang, K. Zhang, and R. Liu, "Influence of air supply pressure on atomization characteristics and dust-suppression efficiency of internal-mixing air-assisted atomizing nozzle," Powder Technology, vol. 355, pp. 393-407, 2019.

[22] P. Wang, Y. Shi, L. Zhang, and Y. Li, "Effect of structural parameters on atomization characteristics and dust reduction performance of internal-mixing air-assisted atomizer nozzle," Process Safety and Environmental Protection, vol. 128, pp. 316-328, 2019.

[23] Y. Li, P. Wang, R. Liu, and R. Gao, "Optimization of structural parameters and installation position of the wall-mounted air cylinder in the fully mechanized excavation face based on CFD and orthogonal design," Process Safety and Environmental Protection, vol. 130, pp. 344-358, 2019.

[24] Y. J. Li, P. F. Wang, R. H. Liu, Y. D. Jiang, and H. Han, "Determination of the optimal axial-to-radial flow ratio of the wall-mounted swirling ventilation in fully mechanized excavation face," Powder Technology, 2019.

[25] H. Han, P. F. Wang, Y. J. Li, R. H. Liu, and C. Tian, "Effect of water supply pressure on atomization characteristics and dust-reduction efficiency of internal mixing air atomizing nozzle," Advanced Powder Technology, 2019.

[26] C. Xu, W. Nie, Z. Liu, H. Peng, S. Yang, and Q. Liu, "Multifactor numerical simulation study on spray dust suppression device in coal mining process," Energy, vol. 182, pp. 544-558, 2019.

[27] S. Yin, W. Nie, Q. Liu, and Y. Hua, "Transient CFD modelling of space-time evolution of dust pollutants and air-curtain generator position during tunneling," Journal of Cleaner Production, vol. 239, Article ID 117924, 2019.

[28] P. R. Amyotte, M. J. Pegg, and F. I. Khan, “Application of inherent safety principles to dust explosion prevention and mitigation," Process Safety and Environmental Protection, vol. 87, no. 1, pp. 35-39, 2009.

[29] D. Prostanski, "Use of air-water spraying systems for improving dust control in mines," Journal of Sustainable Mining, vol. 12, no. 2, pp. 29-34, 2013.

[30] H. Wang, Y. Du, X. Wei, and X. He, "An experimental comparison of the spray performance of typical water-based dust reduction media," Powder Technology, vol. 345, pp. 580-588, 2019.

[31] H. Wang, W. Xuan, Z. Zhang, and B. Qin, "Experimental investigation of the properties of dust suppressants after magnetic-field treatment and mechanism exploration," Powder Technology, vol. 342, pp. 149-155, 2019.

[32] W. Yin, G. Zhou, and D. Gao, "Simulation analysis and engineering application of distribution characteristics about multi-stage atomization field for cutting dust in fully mechanized mining face," Advanced Powder Technology, vol. 30, no. 11, pp. 2600-2615, 2019.

[33] G. Zhou, "Research of theory about dust prevention by watercloud and relevant techniques for fully-mechanized caving coal face," Shandong University of Science and Technology, Qingdao, China, Dissertation, 2009.

[34] Z. X. Li, G. Y. Sun, and J. B. Wang, "Numerical simulation of water injection into coal seam throughlong drill hole and determination of its reasonable parameters," Journal of China Coal Society, vol. 26, pp. 389-393, 2001.

[35] Z. X. Li, G. Z. Hai, and S. Y. Qin, "Numerical modeling of water distribution of infusion in coal seams," Coal Engineering, vol. 26, pp. 14-17, 1997.

[36] Z. B. Zhao, "Study of technology of variable-frequency pulse water infusion into coal seam," Journal of Mining \& Safety Engineering, vol. 25, pp. 486-489, 2008.

[37] W.-M. Cheng, W. Nie, G. Zhou, Y. Yu, Y. Ma, and J. Xue, "Research and practice on fluctuation water injection technology at low permeability coal seam," Safety Science, vol. 50, no. 4, pp. 851-856, 2012.

[38] W. M. Cheng, S. Cao, G. Zhou, L. J. Chen, Y. B. Yu, and P. Gang, "Dust control and cooling technology of hybrid water injection," Safety in Coal Mine, vol. 44, pp. 64-67, 2013.

[39] Y. B. Yu, J. Y. Jiang, W. M. Cheng, L. J. Chen, G. Zhou, and G. Wang, "Experimental study on permeability properties of coal seam under high pressure water injection," Journal of Mining \& Safety Engineering, vol. 32, pp. 144-149, 2015.

[40] S. G. Li and J. C. Xu, "Experimental study on permeability of soft coal sample with electro-hydraulic servo controlled testing system," Chinese Journal of Geotechnical Engineering, vol. 23, pp. 68-70, 2001.

[41] W. Cheng, Z. Liu, H. Yang, and W. Wang, "Non-linear seepage characteristics and influential factors of water injection in gassy seams," Experimental Thermal and Fluid Science, vol. 91, pp. 41-53, 2018.

[42] L. Z. Jin, W. Ni, Q. Song, and W. Wei, "Apenetrative addictive for water infusion in coal seams," Journal of Beijing University of Science and Technology (English Edition), vol. 10, pp. 16-20, 2003.

[43] M. Xu, H. Qiu, and T. Fan, "Numerical simulation of effect of coal body deformation on wetting of low pressure water injection in coal seam," Coal Technology, vol. 35, pp. 166-168, 2016.

[44] S. Y. Qin and W. H. Qin, "Engineering experiment research of the quantity theoretical orthogonal design optimal method for the coal-seam injection parameters," Engineering Science, vol. 5, pp. 52-55, 2003.

[45] S. Y. Qin, W. Qin, and J. F. Zhao, "BP neural network method application in feasibility evaluation of water infusion for coal seam," Journal of Geological Hazard and Control, vol. 17, pp. 87-90, 2006.

[46] L. L. Li, "Simulation of coal injection effect analysis," Computer Simulation, vol. 29, pp. 234-237, 2012.

[47] Z. G. Yuan, H. T. Wang, G. Z. Hu, N. P. Hu, and X. G. Fan, "Fisher discriminate analysis model and application of classifying difficulty degree of water infusion for coal seam," Journal of China Coal Society, vol. 36, pp. 639-643, 2011.

[48] F. Arpino, A. Carotenuto, M. Ciccolella, G. Cortellessa, N. Massarotti, and A. Mauro, "Transient natural convection in 
partially porous vertical annuli," International Journal of Heat and Technology, vol. 34, no. 2, pp. S512-S518, 2016.

[49] F. Colangelo, G. De Luca, and C. Ferone, A. Mauro, Experimental and numerical analysis of thermal and hygrometric characteristics of building structures employing recycled plastic aggregates and geopolymer concrete," Energies, vol. 6, no. 11, pp. 6077-6101, 2013.

[50] A. Carotenuto, P. Marotta, N. Massarotti, A. Mauro, and G. Normino, "Energy piles for ground source heat pump applications: comparison of heat transfer performance for different design and operating parameters," Applied Thermal Engineering, vol. 124, pp. 1492-1504, 2017.

[51] H. K. Wang, W. Nie, H. H. Zhang et al., "A synthesis of a dust suppressant using the cellulose extracted from maize straw," Starch-Starke, 2019.

[52] H. Wang, X. Wei, Y. Du, and D. Wang, "Effect of watersoluble polymers on the performance of dust-suppression foams: wettability, surface viscosity and stability," Colloids and Surfaces A: Physicochemical and Engineering Aspects, vol. 568, pp. 92-98, 2019.

[53] H. Jin, W. Nie, H. Zhang et al., "Preparation and characterization of a novel environmentally friendly coal dust suppressant," Journal of Applied Polymer Science, vol. 136, no. 17 , p. 47354, 2018.

[54] H. Peng, W. Nie, H. Yu et al., "Research on mine dust suppression by spraying: development of an air-assisted PM10 control device based on CFD technology," Advanced Powder Technology, vol. 30, no. 11, pp. 2588-2599, 2019. 


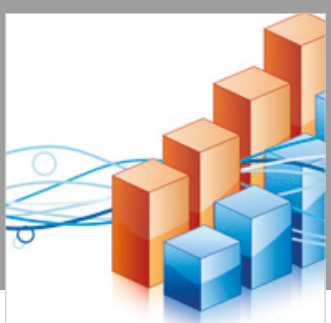

Advances in

Operations Research

\section{-n-m}
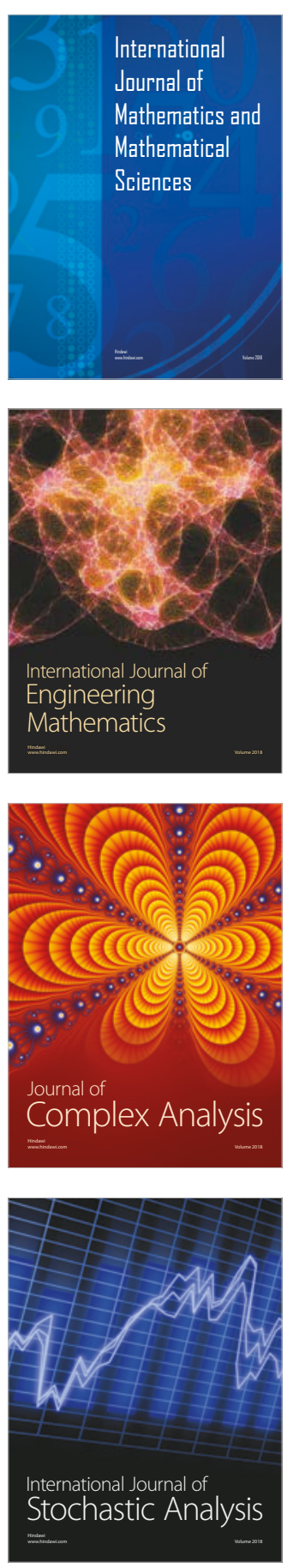
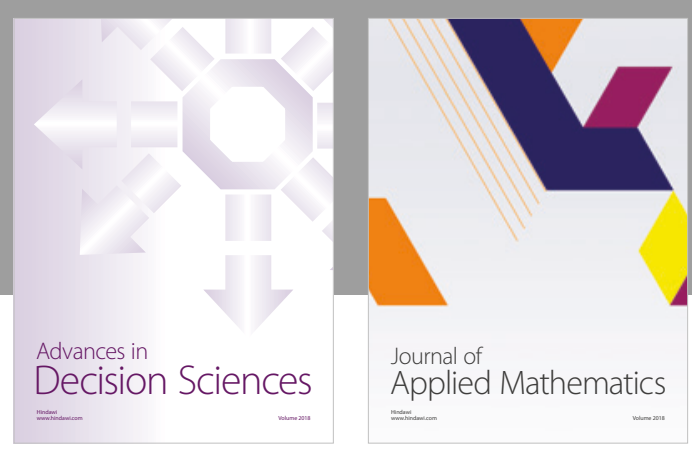

Journal of

Applied Mathematics
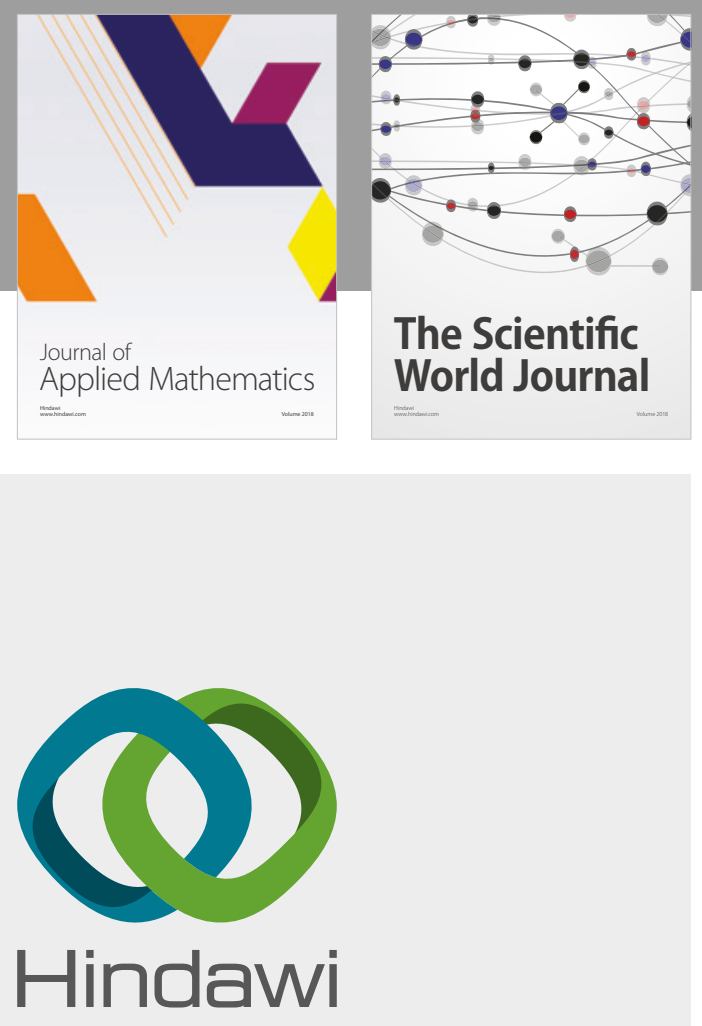

Submit your manuscripts at

www.hindawi.com

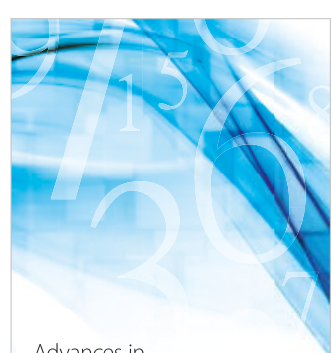

Advances in
Numerical Analysis
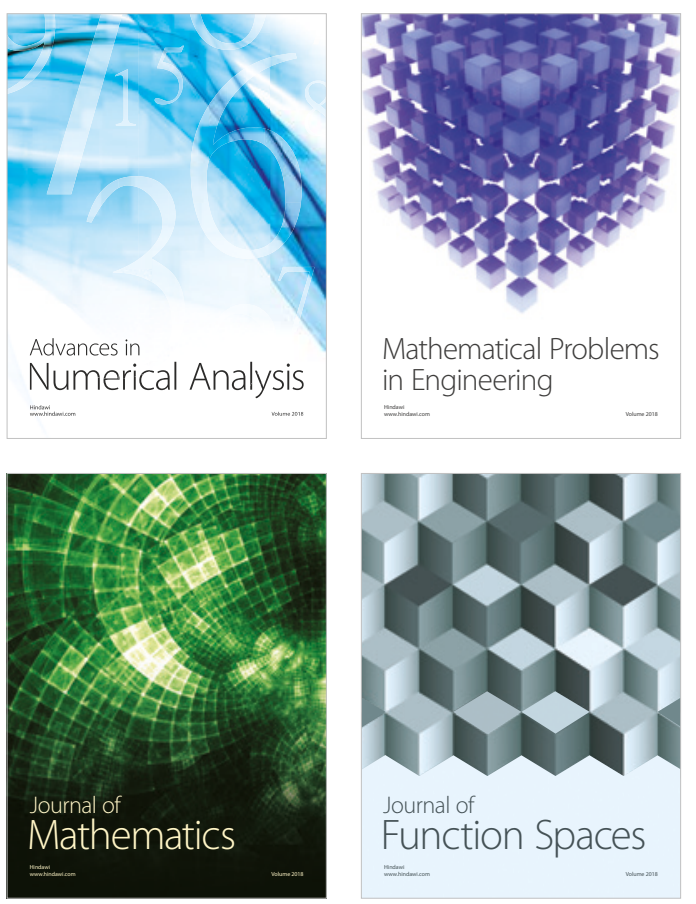

Mathematical Problems in Engineering

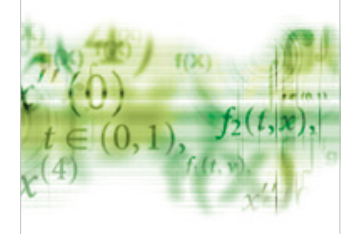

International Journal of

Differential Equations

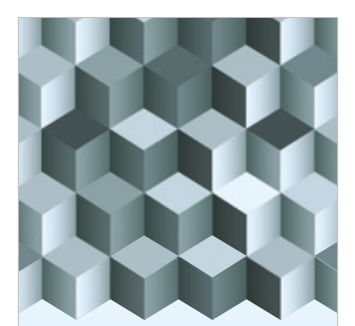

Journal of

Function Spaces

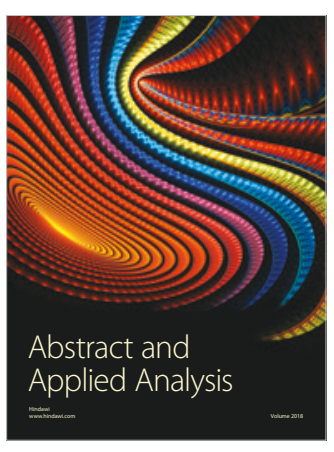

The Scientific

World Journal

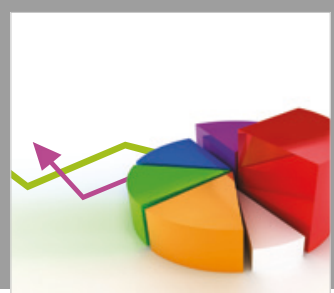

Journal of

Probability and Statistics
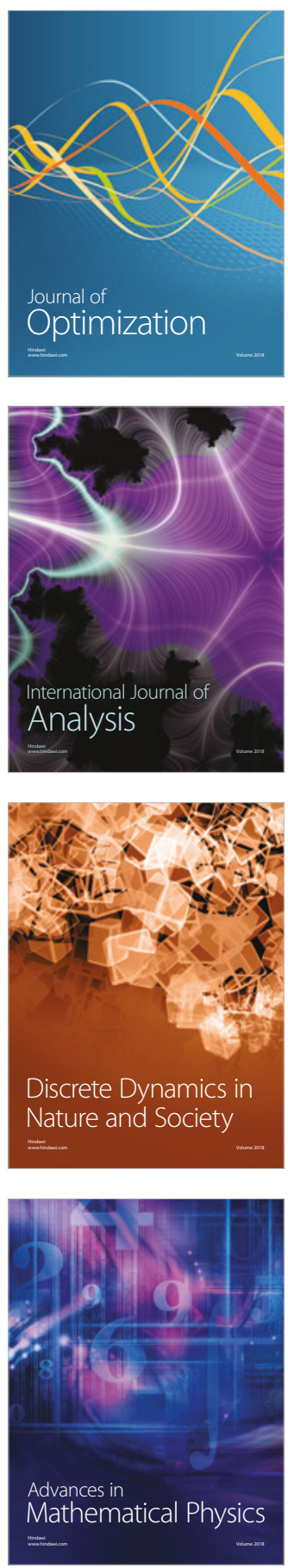